\title{
Review of Alterations in Perlecan-Associated Vascular Risk Factors in Dementia
}

\author{
Amanda L. Trout ${ }^{1}$, Ibolya Rutkai ${ }^{2,3}$, Ifechukwude J. Biose ${ }^{2}$ and Gregory J. Bix ${ }^{2,3, *}$ \\ 1 Department of Neurology, University of Kentucky, Lexington, KY 40536, USA; A.trout@uky.edu \\ 2 Department of Neurosurgery, Clinical Neuroscience Research Center, Tulane University School of Medicine, \\ New Orleans, LA 70112, USA; irutkai@tulane.edu (I.R.); ibiose@tulane.edu (I.J.B.) \\ 3 Tulane Brain Institute, Tulane University, New Orleans, LA 70118, USA \\ * Correspondence: gbix@tulane.edu; Tel.: +504-988-3564
}

Received: 18 November 2019; Accepted: 16 January 2020; Published: 20 January 2020

check for updates

\begin{abstract}
Perlecan is a heparan sulfate proteoglycan protein in the extracellular matrix that structurally and biochemically supports the cerebrovasculature by dynamically responding to changes in cerebral blood flow. These changes in perlecan expression seem to be contradictory, ranging from neuroprotective and angiogenic to thrombotic and linked to lipid retention. This review investigates perlecan's influence on risk factors such as diabetes, hypertension, and amyloid that effect Vascular contributions to Cognitive Impairment and Dementia (VCID). VCID, a comorbidity with diverse etiology in sporadic Alzheimer's disease (AD), is thought to be a major factor that drives the overall clinical burden of dementia. Accordingly, changes in perlecan expression and distribution in response to VCID appears to be injury, risk factor, location, sex, age, and perlecan domain dependent. While great effort has been made to understand the role of perlecan in VCID, additional studies are needed to increase our understanding of perlecan's role in health and in cerebrovascular disease.
\end{abstract}

Keywords: perlecan; extracellular matrix; basement membrane; VCID; vascular risk factors; and dementia

\section{Extracellular Matrix and Perlecan}

The basement membrane (BM) is a thin layer of extracellular matrices (ECMs) that anchors the epithelium (e.g., respiratory tract), mesothelium (e.g., peritoneal cavity), and endothelium (e.g., vasculature) to the underlying smooth muscle and connective tissue [1,2]. This specialized form of ECM is a scaffolding of interwoven macromolecules and proteins that provide structural support, contribute to differentiation, and serve as a signaling platform (reviewed in [3-6]). This dynamic interface represents a delicate balance among protein synthesis, proteolysis, and metabolism [4,7-9], contributing to cellular plasticity and tissue specificity. The vascular BM not only mediates compartmentalization but also creates a selective barrier to infiltrating proteins and cells in parts of the body, such as the brain, sustaining blood-brain barrier (BBB) integrity [4,7-9]. Ranging from 20 to $200 \mathrm{~nm}$, the ECM consists of over 20 proteins, including a number of glycoproteins such as laminins, collagen IV, nidogens, and heparan sulfate proteoglycans (HSPG) (reviewed in [3-6]).

Perlecan is one of the most abundant heparan sulfate proteoglycans (HSPG) [10], encoded by HSPG2 on chromosome 1 [11-13]. The role of perlecan has been studied in a multitude of cellular processes ranging from cell adhesion [14,15], wound healing [16], angiogenesis [17-20], neuroprotection [18,21], and normal development of the heart, bone, cartilage, and brain [22-27]. Perlecan consists of a core protein with a size between $467 \mathrm{kDa}$ (humans) and over $750 \mathrm{kDa}$ with the addition of three to four glycosaminoglycan (GAG) side chains $[28,29]$. This multi-domain molecule is composed of five distinct regions, termed domains one to five (DI-V) (reviewed in [30-32]). DI contains 
a Sperm, Enterokinase and Agrin fold with GAG and heparan sulfate (HS) attachment sites that has been proposed to facilitate the release of heparan binding growth factors in wound healing [33-35]. This domain has a distinct, perlecan specific protein motif that does not share homology with any other proteins [36]. Truncated perlecan DI, found in $\mathrm{Hspg}^{-/-}$or perlecan knock out mice, has been associated with complete loss of function, embryonic lethality ( E10-12), enlarged ventricles, smaller brains, and weakened vasculature leading to severe bleeding and heart malformations [24,25,37]. Rescuing this phenotype via cartilage-specific perlecan $\left(\mathrm{Hspg}_{2}{ }^{-/}\right.$; Col2a1- $\left.\mathrm{Hspg}_{2}{ }^{T G /-}\right)$ knock in [38] results in 50\% more survivability at $\sim$ E10-12 [39], normal cephalic development [39], intact BBB [40], but decreased neurogenesis [41], and endothelial [42] and pericyte [40] dysfunction following injury. Interestingly, an altered attachment site of DI for HS side chains, due to the lack of exon $3\left(\mathrm{Hspg}_{2} 2^{\Delta 3 / \Delta 3}\right)$, did not affect perlecan expression [43], nor associated with birth defects or phenotypic developmental abnormalities other than congenital cataracts [43]. However, vascular injury, induced by the ligation of the distal carotid artery in the $H_{s p g} 2^{\Delta 3 / \Delta 3}$ mice has been found to contribute to an increased intimal hyperplasia [44]. Moreover, smooth muscle cells, isolated from $\mathrm{Hspg}_{2}{ }^{\Delta 3 / \Delta 3}$ have shown altered binding of fibroblast growth factor (FGF-2) and a greater proliferation capacity when compared with wild type [43]. DII, containing four low density lipoprotein (LDL) receptor motifs and an immunoglobulin-like (IG) fold, is suggested to play a role in development via wingless (Wnt), LDL, and calcium signaling [45-48], whereas DIII contains laminin epidermal growth factor (EGF) and laminin IV type A (laminin B) domains that can directly bind fibroblast growth factor [48-50]. Perlecan-deficient endothelial cells, via antisense targeted against DIII, have been associated with an increased thrombotic occlusion rate, possibly due to the inability to bind FGF [51]. A C1532Yneo mutation in DIII in perlecan hypomorph $\left(\mathrm{pln}^{-1-}\right)$ mice results in more than $90 \%$ reduction in perlecan expression [52]. These mice display musculoskeletal tissue disorders, resembling the Schwartz-Jampel syndrome (SJS) in humans [52], a disease due to HSPG2 gene mutation [53-60]. Furthermore, larger infarcts and worse functional deficits have been reported in perlecan hypomorph mice following middle cerebral artery occlusion (MCAo) $[18,61]$. The repeating Ig C2-type modules in DIV, with or without additional GAG attachment site, determine the adhesion properties of perlecan to other ECM proteins [47,62]. The perlecan C-terminal, termed endorepellin or DV, contains three laminin G-like subdomains with dual EGF-like domains $[36,48]$ and can be cleaved by proteases such as matrix metalloproteases (MMPs) or cathepsins [18,61,63-67]. DV has been linked to anti-angiogenic activity in tumor growth [20], pro-angiogenic and neuroprotective effects in ischemia [19] as well as to amyloid beta $(A \beta)$ toxicity $[17,21,68]$. Interestingly, the third laminin G-like subdomain (LG3) appears to be particularly bioactive and may convey much of DV's reported biological activity $[18,20]$.

Overall, these observations provide strong evidence that perlecan is essential for brain, bone, heart, and cartilage development and plays a critical role in the maintenance of homeostatic balance in the brain following injury.

\section{Perlecan and the Cerebrovasculature in Disease and Stroke}

The cerebral vasculature is composed of distinct types of vessels, i.e., pial arteries, arterioles, capillaries, or venules that are structurally and biochemically different, contributing to their specificity. The pial arteries consist of three main layers from inside out: the tunica intima that contains both endothelial cells and BM, surrounded by the tunica media, compromised by smooth muscle cells and the most outer part, the tunica adventitia (or connective tissue). As these vessels dive into the brain parenchyma and branch into smaller and smaller segments, they give rise to brain arteriole and capillary networks, while losing their smooth muscle (SMC) coverage but gaining more pericytes and astrocytic endfeet. All of these cells regulate and/or secrete perlecan [15,40,69-76]. Studies investigating the effects of altered perlecan expression are contradictory, ranging from pro vs. anti-angiogenic $[17,18,70,77]$, or associated or not with plaque and thrombotic core proteins [78-84]. The role of perlecan may depend on the model, size of the blood vessel, sex (female vs. male), and age. 
Cerebrovascular diseases represent one of the top five most common causes of death in the United States [85]. As we age, our vasculature undergoes degeneration due to the accumulation of mechanical and sheer stress induced by innate fluctuations in blood pressure [86]. Arteriolosclerosis, arterial stiffness, and reduced compliance, are among the first pathologies to present, leading to altered cerebrovascular blood flow (CBF) and ECM protein metabolism, or the remodeling of ECM. Moreover, proteases known to cleave perlecan such as matrix MMPs or cathepsins $[18,61,63-67]$ increase in cerebrovascular diseases (reviewed in [87]). Fluctuation of perlecan expression has been reported in aging; perlecan levels in mouse brain were high at 3 months, decreased at 8 months, followed by a secondary increase at 16 months of age [88]. However, a study by Kerever et al. reported no change in perlecan expression in the subventricular zone of aged mice without comorbidity [89]. Age-related structural changes are associated with decreased CBF, contributing to cell senescence, damage, and dementia [90-98]. A term that encompasses cognitive decline associated with vascular change is Vascular contributions to Cognitive Impairment and Dementia or VCID. VCID is the second leading cause of dementia [99-101] behind Alzheimer's disease (AD) [102-105] with many of the same vascular risk factors, such as, age, sex, hypertension [106], atherosclerosis, and diabetes mellitus (DM) [107-114]. How metabolic changes such as high glucose, high insulin, or high free fatty acid levels individually or in combination affect perlecan distribution and expression is reviewed in Table 1. VCID etiology ranges from cerebrovascular disruption, seen in small vessel diseases of the brain, including arteriolosclerosis, and cerebral amyloid angiopathy (CAA, pathologic accumulation of amyloid beta $(\mathrm{A} \beta)$ protein in brain blood vessels), to the profound symptomatic damage following acute stroke. These vascular risk factors may increase $\mathrm{BM}$ thickness contributing to the narrowing of vascular lumen and to the disruption of BBB integrity. Changes in the BBB are dynamic, as it opens and closes multiple times within the first hours to days after ischemic injury [115]. This disrupted BBB provides a pathway for inflammatory cells that may infiltrate the brain and release additional proteases, free radicals, chemokines, and cytokines [116-118]; further contributing to altered ECM synthesis of matrix proteins or proteolysis, splice variants, smooth muscle cell migration and proliferation [119]. The extent of the injury and remodeling in the ECM is determined by the vascular injury, loss of blood flow, resultant inflammation, and ultimately the changes in oxygen and nutrient supply to the neurons and their support cells (glia and immune cells).

Table 1. Metabolic Changes and Perlecan.

\begin{tabular}{|c|c|c|c|c|}
\hline Model [Organism], Age & Tissue/Sample & Sex & $\begin{array}{c}\text { Findings: Changes in } \\
\text { Perlecan } \\
\text { (Domain, Antibody; } \\
\text { Where Applicable) }\end{array}$ & Reference \\
\hline $\begin{array}{c}\text { STZ and osteoarthritis } \\
\text { (ACLT) [WKY rats], 5-6 } \\
\text { mo }\end{array}$ & $\begin{array}{l}\text { Condylar femur, } \\
\text { tibial articular } \\
\text { cartilage }\end{array}$ & Male & $\begin{array}{c}\downarrow \text { mRNA and protein with } \\
\text { hyperglycemia } \\
\uparrow \text { mRNA with } \\
\text { hyperglycemia and } \\
\text { osteoarthritis }\end{array}$ & [120] \\
\hline $\begin{array}{c}\mathrm{db} / \mathrm{db} \text { and } \mathrm{db} /+ \\
\text { non-diabetic [mice], } \\
\text { 10-12 wk }\end{array}$ & Kidney & Mixed & $\begin{array}{c}\text { - (no change) in perlecan } \\
\text { (DIV, clone } \\
\text { A7L6-MAB1948) }\end{array}$ & [121] \\
\hline $\begin{array}{c}\text { STZ-DN } \\
\text { [C57BL/6 mice], 6-8 wk }\end{array}$ & Kidney & Male & $\begin{array}{l}\downarrow \text { perlecan core protein, no } \\
\text { change in mRNA stability } \\
\text { in DN vs. control }\end{array}$ & [122] \\
\hline $\begin{array}{l}\text { STZ [SD rats], } 5 \text { and } 12 \\
\text { mo }\end{array}$ & Kidney & Male & $\begin{array}{c}\text { - (no change) in perlecan } \\
\text { (DI, clone16) }\end{array}$ & [123] \\
\hline STZ [C57Bl/6 mice], 6 mo & Liver & Male & $\downarrow$ perlecan & [124] \\
\hline
\end{tabular}


Table 1. Cont.

\begin{tabular}{|c|c|c|c|c|}
\hline Model [Organism], Age & Tissue/Sample & Sex & $\begin{array}{c}\text { Findings: Changes in } \\
\text { Perlecan } \\
\text { (Domain, Antibody; } \\
\text { Where Applicable) }\end{array}$ & Reference \\
\hline DN [Human] & n. sp. & n. sp. & $\begin{array}{c}\text { Association between } \\
\text { HSPG2 variant } \\
\text { and DN }\end{array}$ & [125] \\
\hline $\begin{array}{c}\text { Focal Segmental } \\
\text { Glomerulosclerosis and } \\
\text { DN [Human; CD } 44^{+/+} \\
\text {and CD } 44^{-/-} \text {and } 24 \mathrm{wk} \\
\text { BTBR ob/ob mice] }\end{array}$ & Kidney & $\begin{array}{l}\text { Male } \\
\text { (mice) }\end{array}$ & $\begin{array}{c}\uparrow \text { perlecan (DIV, clone } \\
\text { A7L6) }\end{array}$ & [126] \\
\hline DN [Human] & Kidney & n. sp. & $\begin{array}{c}\uparrow \text { perlecan (DIV, clone } \\
\text { A7L6) }\end{array}$ & [127] \\
\hline $\begin{array}{l}\text { Non-ischemic kidney } \\
\text { injury, db/db } \\
\text { (BKS.Cg-m }+/+ \text { Lepr }{ }^{\mathrm{db}} \text {, } \\
\text { diabetic) and db/m } \\
\text { non-diabetic [mice], } 20 \\
\text { wk }\end{array}$ & Kidney & Male & $\begin{array}{c}\downarrow \text { Glomerular level in } \\
\text { diabetic vs. } \\
\text { non-diabetic }\end{array}$ & [128] \\
\hline $\begin{array}{c}\text { IDDM/DN } \pm \\
\text { albuminuria [Human] }\end{array}$ & $\begin{array}{l}\text { Genomic DNA } \\
\text { from leukocytes }\end{array}$ & n. sp. & $\begin{array}{l}\text { Association of a Bam } \mathrm{Hl} \\
\text { HSPG2 polymorphism in } \\
\text { DI with diabetic } \\
\text { nephropathy }\end{array}$ & [129] \\
\hline $\begin{array}{l}\text { IDDM/NIDDM } \pm \\
\text { diabetic retinopathy }\end{array}$ & Eye & n. sp. & - (no change) & [130] \\
\hline $\begin{array}{l}\text { High glucose, } \\
\text { inflammation, Short } \\
\text { treatment [Human] }\end{array}$ & $\begin{array}{l}\text { Human umbilical } \\
\text { cord vein } \\
\text { endothelial cells }\end{array}$ & n. sp. & $\begin{array}{c}\uparrow \text { perlecan following IL-1 } \beta \\
\text { treatment } \\
\uparrow \text { HS chains by TNF }\end{array}$ & [131] \\
\hline $\begin{array}{l}\text { Wound healing [Retired } \\
\text { breeder Lewis rats and } \\
\text { Zucker Diabetic Fatty } \\
\text { diabetic rats] }\end{array}$ & Skin & Male & $\begin{array}{l}\uparrow \text { perlecan (DI, clone } \\
\mathrm{CCN}-1 \text { ) in healing and } \\
\text { blood vessel formation } \\
\text { with chitosan scaffolds }\end{array}$ & [35] \\
\hline $\begin{array}{c}\text { DN, non-diabetic } \\
\text { [Human], } \\
\text { mean age of } 64 \text { yr and } \\
39.3 \mathrm{yr}\end{array}$ & $\begin{array}{l}\text { Parietal epithelial } \\
\text { cells }\end{array}$ & Mixed & $\begin{array}{c}\uparrow \mathrm{TGF} \text {, advanced glycation, } \\
\text { and high glucose }\end{array}$ & [132] \\
\hline High glucose [Human] & $\begin{array}{l}\text { Trophoblast cell } \\
\text { line 3A-Sub-E }\end{array}$ & n. sp. & $\begin{array}{c}\downarrow \text { perlecan (DIV, clone } \\
\text { A7L6) }\end{array}$ & [133] \\
\hline $\begin{array}{c}\text { [Human] gestational age } \\
5-7 w k, 15-26 \text { wk, 36-40 } \\
\text { wk }\end{array}$ & Placenta & n. sp. & $\begin{array}{c}\downarrow \text { (DIV, clone A7L6) during } \\
\text { placental maturation in } \\
\text { normal pregnancies } \\
\uparrow \text { in gestational diabetes }\end{array}$ & [134] \\
\hline
\end{tabular}

Abbreviations. $\uparrow:$ increase; $\downarrow$ : decrease; -: no change; ACLT: anterior cruciate ligament transection; BTBR ob/ob: black and tan, brachyuric, obese (leptin-deficiency); DI: domainI; DIV: domain IV; db: diabetic (leptin defiency); DN: diabetic nephropathy; HS: Heparan sulphate; HSPG2: Heparan sulphate proteoglycan 2; IDDM: insulin-dependent diabetes mellitus; mo: month; NIDDM: non-insulin-dependent diabetes mellitus; $\mathrm{n}$. sp.: not specified; SD: Sprague-Dawley; STZ: streptozotocin; TGF: transforming growth factor; TNF: tumor necrosis factor; wk: week; WKY: Wistar Kyoto; yr: year.

Atherosclerosis, a common cause and comorbidity in stroke and vascular dementia, has been linked with the distribution of ECM proteins (e.g., perlecan) in the walls of peripheral arteries. Atherosclerosis, a disease of large and medium sized arteries, develops in stages, starting with intimal hyperplasia due to lipid accumulation, followed by development of plaques and thrombosis leading to vessel occlusion 
(ischemic stroke) or rupture (hemorrhagic stroke) [135-138]. Perlecan has been linked to lipid retention in the vasculature [83], possibly through the LDL receptor motifs region in DII (additional studies on perlecan and atherosclerotic plaques are outlined in Table 2). Increased BM perlecan expression has been correlated with atherosclerotic lesions in experimental mice [79,81], non-human primates [139], and in humans [80]. Interestingly, perlecan expression was found to be increased in aged human cerebral arteries but decreased as the lesion progressed [140]. Haung et al. have shown that perlecan accumulation via angII-driven mechanisms preceded the progression of atherosclerosis [81]. This suggests that perlecan accumulation may increase endothelial barrier disruption resulting in lesion formation via increased deposition of LDL. Moreover, the loss of perlecan has been associated with less atherosclerosis in early lesions of mice without effect on the lipoprotein profile [83,141].

Table 2. Atherosclerosis and Perlecan.

\begin{tabular}{|c|c|c|c|c|}
\hline Model [Organism], Age & Tissue/Sample & Sex & $\begin{array}{c}\text { Findings: Changes in } \\
\text { Perlecan } \\
\text { (Domain, Antibody; } \\
\text { Where Applicable) }\end{array}$ & Reference \\
\hline $\begin{array}{l}\text { ApoE and LDLR KOs } \\
\text { [mice] }\end{array}$ & Aorta & Mixed & $\begin{array}{l}\uparrow \text { perlecan in intima and } \\
\text { smooth muscle cells }\end{array}$ & {$[79]$} \\
\hline [Human] & Aorta & Male & $\begin{array}{l}\uparrow \text { perlecan (DIV, clone } \\
\text { A7L6, RT-794-B1) with age } \\
\text { and lesion progression }\end{array}$ & {$[80]$} \\
\hline $\begin{array}{c}\text { LDLR }-/- \text { and AT1a-/- } \\
\text { LDLR-/- [mice] }\end{array}$ & Aorta & Female & $\uparrow$ perlecan with lesion & [81] \\
\hline $\begin{array}{l}\text { AngII and Western diet } \\
\text { [Biglycan deficient/WT } \\
\text { mice] }\end{array}$ & $\begin{array}{l}\text { Aorta, } \\
\text { carotid artery }\end{array}$ & Mixed & $\begin{array}{c}\uparrow \text { perlecan with Western } \\
\text { diet in biglycan deficient } \\
\text { mice not WT } \\
\text { - No change in perlecan } \\
\text { by angII }\end{array}$ & {$[82]$} \\
\hline $\begin{array}{l}\text { ApoE0/Hspg } 2^{\Delta 3 / \Delta 3}, \\
\text { ApoE0, and C57BL/6 } \\
\text { [mice], } 15 \text { and } 33 \mathrm{wk}\end{array}$ & Aorta & Mixed & $\begin{array}{c}\downarrow \text { perlecan (core protein, } \\
\text { R14) at } 15 \text { and } 33 \text { wk with } \\
\text { smaller lesion } \\
\text { - No change in perlecan } \\
\text { mRNA }\end{array}$ & [83] \\
\hline $\begin{array}{l}\text { Normal or Paigen diet } \\
\text { [Heterozygous } \\
\text { perlecan-deficient and } \\
\text { apoE0 mice], } \\
12,20 \text { and } 24 \mathrm{wk}\end{array}$ & Aorta & Mixed & $\begin{array}{l}\text { - No change in lipid } \\
\text { profile upon perlecan } \\
\text { deletion } \\
\downarrow \text { atherosclerosis in young } \\
\text { heterozygous } \mathrm{KO} \text { /apoE0 } \\
\uparrow \text { perlecan staining in } \\
\text { subendothelial region with } \\
\text { atherosclerosis }\end{array}$ & {$[141]$} \\
\hline [Human] 32-88 yr & $\begin{array}{l}\text { Atherosclerotic } \\
\text { carotid plaques, } \\
\text { control iliac, } \\
\text { mesenteric arteries, } \\
\text { and aorta }\end{array}$ & Mixed & $\begin{array}{l}\downarrow \text { perlecan (R14) protein } \\
\text { and mRNA in } \\
\text { atherosclerotic group }\end{array}$ & {$[84]$} \\
\hline
\end{tabular}

Abbreviations. $\uparrow:$ increase; $\downarrow$ : decrease; -: no change; AngII: Angiotensin II; ApoE: apolipoprotein E; ApoE0: apoE gene knockout; AT1a: angiotensin II subtype-1a; DIV: domain IV; Hspg $2^{\Delta 3 / \Delta 3}$ : Heparan sulphate proteoglycan 2 with deleted exon 3; KO: knock out; LDLR: low density lipoprotein receptor; wk: week; WT: wild type; yr: year.

Also, decreased heparan sulfate and perlecan levels were detected in fully developed atherosclerotic lesions of tunica intima, derived from non-diabetic and Type 2 non-insulin-dependent diabetes mellitus patients [142], as well as from those with carotid stenosis [143], respectively. Hence, it is plausible that the distribution of various ECM components, especially perlecan, drives the initiation and 
progression of atherosclerosis. In contrast, an earlier study by Hollmann et al. reported decreased perlecan expression, associated with advancing age and severity of atherosclerosis, in both normal and atherosclerotic regions of human aorta [80]. The difference between this study and others may lie in the method of tissue preparation and perlecan detection. Additional contradictory studies show perlecan preventing atherosclerosis $[84,144,145]$. In an in vitro model, increased endothelial cell HSPG/perlecan production led to a reduction of the atherosclerotic lesions [146].

Amyloid that accumulates within the vasculature, CAA, and brain parenchyma, forms plaques (AD) that disrupt the distribution of perlecan (Table 3) [147-149], decreases the ability of SMC to bind perlecan [150], and contributes to vascular wall weakening [147]. Modifications to the sulfate content of the specific GAG chains of perlecan were also found to be critical to the binding of amyloid [151]. In a systematic family-base genome-wide association and meta-analysis that included 15 million imputed variants from 3524 European subjects, HSPG variant rs2445130-A ( $\mathrm{p}=8 \times 10^{-7}$ ) had an increased association of AD status and onset age [152]. Furthermore, HSPGs have been found in amyloid deposits in congophilic angiopathy as well as in neuritic plaques [153]. Similarly, Lepelletier et al. reported an association in amyloid regions with high perlecan in patients with a Braak stage $>2$ [154] when using antibodies targeting DIV. However, a study by Verbeek et al. found agrin, and a lesser extent glypican and syndecan, to be the major HSPGs associated with amyloid, whereas perlecan was not found in hippocampal nor neocortical plaques when using antibodies against DI-DII and DIV [155]. The lack of perlecan staining on amyloid positive vessels of CAA patients has been reported as well [156]. These observations suggest the possibility that the pathologic absence of perlecan/DV contributes to, and/or is the result of cerebrovascular $A \beta$ accumulation. Functionally, treatment with a recombinant DV of perlecan has been demonstrated to block the deleterious effects of amyloid on brain endothelial cells [17] via $\alpha 5 \beta 1$ integrin receptor, a key angiogenesis receptor, downregulated after brain development, and only to be upregulated in response to ischemic brain injury [157]. The role of perlecan in amyloid accumulation and clearance may be intricately regulated by cell types, vary among species, and perlecan domain dependent.

Table 3. Amyloid and Perlecan.

\begin{tabular}{|c|c|c|c|c|}
\hline Model [Organism], Age & Tissue/Sample & Sex & $\begin{array}{c}\text { Findings: Changes in } \\
\text { Perlecan } \\
\text { (Domain, Antibody; } \\
\text { Where Applicable) }\end{array}$ & Reference \\
\hline $\begin{array}{l}\text { Subclinical and clinical } \\
\text { AD, Controls [Human] }\end{array}$ & $\begin{array}{l}\text { Post-mortem } \\
\text { Cortex, frontal and } \\
\text { temperoral } \\
\text { superior frontal } \\
\text { gyrus and inferior } \\
\text { temporal gyrus }\end{array}$ & Mixed & $\begin{array}{c}\uparrow \text { in perlecan (DIV, 2501) in } \\
\text { brain regions that have } \uparrow \\
\mathrm{A} \beta \text { assoc. with Braak }>2 \text {. } \\
\text { Similar expression in } \\
\text { subclinical and clinical. } \\
\text { Not associated with } \\
\text { vascular density }\end{array}$ & [154] \\
\hline $\begin{array}{l}11 \text { DAT patients } \\
\text { [Human] }\end{array}$ & $\begin{array}{l}\text { Frontal and } \\
\text { temporal neocortex } \\
\text { and hippocampus }\end{array}$ & Mixed & $\begin{array}{c}\text { Perlecan (DIV, MAB 1948) } \\
\text { and DI-DIIa, MAB95J10) } \\
\text { not associated with senile } \\
\text { plaques and tangles }\end{array}$ & [155] \\
\hline LDLR and apoE mice & $\begin{array}{l}\text { Proximal aortic } \\
\text { tissue }\end{array}$ & Mixed & $\begin{array}{l}\uparrow \text { in perlecan (EY9) } \\
\text { associated with } \\
\text { serum amyloid A }\end{array}$ & [78] \\
\hline $\begin{array}{c}\mathrm{A} \beta \text { stereotaxic injections } \\
\text { TRE4, and C57Bl/6, } 16 \\
\text { mo, [mice] }\end{array}$ & Capillaries & Male & - (no change) in perlecan & [158] \\
\hline
\end{tabular}


Table 3. Cont.

\begin{tabular}{|c|c|c|c|c|}
\hline Model [Organism], Age & Tissue/Sample & Sex & $\begin{array}{c}\text { Findings: Changes in } \\
\text { Perlecan } \\
\text { (Domain, Antibody; } \\
\text { Where Applicable) }\end{array}$ & Reference \\
\hline $\begin{array}{l}\text { TBI/CCI [rat], Juvenile } \\
\text { (17 day old) }\end{array}$ & Ipsilateral cortex & Male & $\begin{array}{c}\uparrow \text { in perlecan (DV, H300), } \\
\text { which coincides to } \\
\text { increased amyloid } \\
\text { expression } \\
\text { - (no change) via WB }\end{array}$ & [159] \\
\hline SAMP8 [mice], 6 mo & Hippocampus & Male & $\begin{array}{l}\text { - (no change) perlecan } \\
\text { and it is not associated } \\
\text { with amyloid granules }\end{array}$ & [160] \\
\hline $\begin{array}{c}\text { APP/PS1 Amyloid } \\
\text { transgenic and c57Bl/6J } \\
\text { [mice], } 12 \mathrm{mo}\end{array}$ & Cerebral tissue & Male & $\begin{array}{c}\uparrow \text { in perlecan associated } \\
\text { with amyloid plaque and } \\
\text { Apo B lipoprotein }\end{array}$ & [161] \\
\hline $\begin{array}{c}\text { Tg2576 and C57BL6 } \\
\text { [mice], } \\
3,7,22 \mathrm{mo}\end{array}$ & $\begin{array}{l}\text { Hippocampal } \\
\text { capillaries and } \\
\text { arteries }\end{array}$ & Mixed & $\begin{array}{l}\text { perlecan } \uparrow 3 \mathrm{~m}, \downarrow 8 \mathrm{~m} \text {, and } \\
\quad \uparrow 16 \mathrm{~m} \text { in capillaries }\end{array}$ & [88] \\
\hline C57BL/6 [mice], & $\begin{array}{l}\text { Cortical and } \\
\text { hippocampal } \\
\text { neurons }\end{array}$ & Mixed & $\begin{array}{c}\uparrow \text { in perlecan DV and LG3 } \\
\text { resulted in } \\
\downarrow A \beta \text { neurotoxicity }\end{array}$ & {$[21]$} \\
\hline C57BL/6 [mice] & $\begin{array}{l}\text { Cerebrovascular } \\
\text { endothelial cell line }\end{array}$ & n. sp. & $\begin{array}{c}\uparrow \mathrm{DV} \text { rescued the } \mathrm{A} \beta \\
\text { decreased proliferation }\end{array}$ & [17] \\
\hline $\begin{array}{l}\text { C57BL/6 [mice] and } \\
\text { [Human] }\end{array}$ & Cortical neurons & n. sp. & $\begin{array}{c}\uparrow \text { in perlecan DV resulted } \\
\text { in } \\
\downarrow \mathrm{A} \beta \text { neurotoxicity }\end{array}$ & [68] \\
\hline APPswe/PS1dE9 [mice] & Vascular & Female & $\begin{array}{c}\downarrow \text { perlecan (DIV, MAB1948) } \\
\text { in } \\
\text { A } \beta \text {-positive vessels }\end{array}$ & [162] \\
\hline LOAD Chinese [human] & $\begin{array}{l}\text { Genomic DNA } \\
\text { from peripheral } \\
\text { venous blood } \\
\text { leukocytes }\end{array}$ & Mixed & $\begin{array}{l}\text { - No association with } \\
\text { LOAD and } \\
\text { HSPG2 polymorphism } \\
\text { (HSPG2 gene, rs } 3767140 \\
\text { C/A) }\end{array}$ & [143] \\
\hline LOAD Finnish [human] & $\begin{array}{l}\text { Genomic DNA } \\
\text { from peripheral } \\
\text { venous blood } \\
\text { leukocytes }\end{array}$ & Mixed & $\begin{array}{c}\uparrow \text { association with LOAD } \\
\text { and HSPG2 polymorphism } \\
\text { in APOE carriers }\end{array}$ & [163] \\
\hline LOAD Jewish [human] & $\begin{array}{l}\text { Genomic DNA } \\
\text { from peripheral } \\
\text { venous blood } \\
\text { leukocytes }\end{array}$ & Mixed & $\begin{array}{l}\text { - No association with } \\
\text { LOAD and } \\
\text { HSPG2 polymorphism } \\
\text { (HSPG2 gene, rs } 3767140 \\
\text { C/A) }\end{array}$ & [164] \\
\hline $\begin{array}{l}\text { FBD, FDD, and AD } \\
\text { [human] }\end{array}$ & $\begin{array}{l}\text { Hippocampal } \\
\text { formation with } \\
\text { temporal cortex } \\
\text { and white matter, } \\
\text { frontal cortex }\end{array}$ & n. sp. & $\begin{array}{c}\downarrow \text { perlecan (DIV, 1948) in } \\
\text { FBD CAA and plaques } \\
\text { and FDD CAA } \\
\text { - No association perlecan } \\
\text { in FDB and FDD diffuse } \\
\text { and all sporadic and } \\
\text { variant AD (CAA plaque, } \\
\text { and diffuse) }\end{array}$ & [165] \\
\hline $\begin{array}{l}\text { LPS verse control treated } \\
\text { [Mustela Vison-mink] }\end{array}$ & Spleen & n. sp. & $\begin{array}{c}\uparrow \text { in perlecan (DIV, 1948) } \\
\text { associated amyloid }\end{array}$ & [166] \\
\hline
\end{tabular}


Table 3. Cont.

\begin{tabular}{|c|c|c|c|c|}
\hline Model [Organism], Age & Tissue/Sample & Sex & $\begin{array}{c}\text { Findings: Changes in } \\
\text { Perlecan } \\
\text { (Domain, Antibody; } \\
\text { Where Applicable) }\end{array}$ & Reference \\
\hline $\mathrm{A} / \mathrm{J}$ mice & Liver & Mixed & $\begin{array}{c}\downarrow \text { perlecan associate with } \downarrow \\
\text { amyloid }\end{array}$ & [167] \\
\hline [human] & $\begin{array}{l}\text { Cerebellum and } \\
\text { cerebrum }\end{array}$ & Mixed & $\begin{array}{c}\downarrow \text { perlecan (DI and DII, } \\
\text { 95J10 and DIV, 1948) in } \\
\text { senile plaques } \\
\text { (non-fibrillar and fibrillar) }\end{array}$ & [168] \\
\hline $\begin{array}{c}\text { AD and CAA (Dutch) } \\
\text { [humans] }\end{array}$ & $\begin{array}{l}\text { Frontal, temporal, } \\
\text { parietal, and } \\
\text { occipital neocortex }\end{array}$ & Mixed & $\begin{array}{c}\downarrow \text { perlecan (DI and DII, } \\
\text { 95J10, and DIV, 1948) in } \\
\text { CAA and in senile plaques }\end{array}$ & [156] \\
\hline
\end{tabular}

Abbreviations. $\uparrow:$ increase; $\downarrow$ : decrease; -: no change; AD: Alzheimer's Disease; A $\beta$ : amyloid beta; A/J: Apoa2 ${ }^{C}$ allele; APP: amyloid precursor protein (swe: Swedish mutation); PS1: presenilin1 (dE9 mutation); CAA: cerebral amyloid accumulation, CCI: control cortical impact, DAT: dementia of the Alzheimer type; DI; domain I; DII: domain II; DIV: domain IV; DV: domain V; FBD: familial British dementia; FDD: familial Danish dementia; HSPG2: Heparan sulphate proteoglycan 2; LDLR: low density lipoprotein receptor; mo: month; n. sp.: not specified; SAMP8: senescence accelerated mouse 8; LOAD: late onset Alzheimer's Disease; LPS: lipopolysaccharide; TBI: traumatic brain injury; WB: western blot; wk: week; yr: year.

Stroke results from the disruption of blood flow to the brain due to the narrowing or occlusion of a vessel (ischemic) or to the weakening of the vessel wall (hemorrhagic). Perlecan was found to be lower in non-human primate models of focal cerebral ischemia [63,169], whereas DV has been demonstrated to increase in rodent models of stroke (endothelin- 1 and tandem common carotid artery occlusion and distal middle cerebral artery occlusion) [18]. The therapeutic potential of recombinant DV after ischemic stroke has been demonstrated by us and others $[18,40]$. Correspondingly, the lack of perlecan, when using hypomorphs, Col2a1-Hspg $2^{T G /-}$ and $\mathrm{Hspg}_{2} 2^{-/-}$mice, was associated with larger infarcts as well as worse functional outcomes after MCAo and decreased neurogenesis, respectively $[18,40]$. Increased perlecan expression was found following traumatic brain injury in mice [75] as well as in human samples from patients with brain arteriovenous malformation [170]. Similarly, Nugent el al. showed increased thrombotic occlusion rates in perlecan-deficient endothelial cells in a porcine carotid artery injury model [51], not surprisingly as perlecan antithrombotic/anticoagulant studies have shown perlecan directly binding to anti-thrombin III [171].

Hypertension is an important risk factor for stroke and vascular dementia and can occur at any age as well as in pregnancy. Vascular remodeling of peripheral and cerebral blood vessels is a common feature of hypertension that has been linked to changes in perlecan (Table 4). Various studies have shown that increased expression and accumulation of collagen IV and elastin in peripheral and cerebral arteries lead to arterial stiffness. However, only a small number of investigators have studied the expression of perlecan in various models of hypertension. McGuire and colleagues were the first to report increased expression of perlecan in the aorta of spontaneously hypertensive rats (SHR), a model of essential hypertension [172]. This finding was corroborated in the aorta of hypertensive rats, induced by high salt diet [173]. Nonaka et al. reported reduced endothelium-dependent relaxation through lower endothelial nitric oxide synthase (eNOS) expression in aortas of perlecan-deficient mice and when perlecan is knocked-down in human aortic endothelial cells [42], suggesting that perlecan may play a role in vasodilation. Furthermore, angII and Western diet have been reported to increase level of perlecan in biglycan deficient mice [82]. Haung et al. [81] showed that perlecan accumulation, via angII-mediated mechanisms, precedes the progression of atherosclerosis, suggesting that perlecan accumulation may facilitate endothelial barrier disruption, resulting in an increased deposition of LDL, the hallmark of atherosclerotic lesion formation. However, no change was detected in perlecan expression in a coarctation of abdominal aorta model of hypertension in rats [174]. In pregnant women, an association was found between increased plasma concentration of perlecan and early onset 
of gestational hypertension [175]. The authors attributed their findings to impaired microvascular perfusion leading to the degradation of glycocalyx of the kidneys. Likewise, early preeclampsia with or without HELLP (hemolysis, elevated liver enzymes, and a low platelet count) syndrome was associated with an increased placental perlecan expression that showed a positive correlation with maternal vascular malperfusion [176]. In contrast, the findings by Guo et al. showed decreased perlecan concentration in urine when compared the gestational hypertension group with controls, indicating glomerular filtration barrier injury and renal dysfunction [177]. Collectively, these observations paint a complex and underexplored role for perlecan in hypertension in the cerebrovasculature and beyond.

Table 4. Hypertension and Perlecan.

\begin{tabular}{|c|c|c|c|c|}
\hline Model [Organism] & Tissue/Sample & Sex & Findings & Reference \\
\hline Preeclampsia [Human] & Urine & Female & $\begin{array}{l}\downarrow \text { perlecan compared to } \\
\text { normotensive controls }\end{array}$ & [177] \\
\hline SHRSP [Rat] & Aorta & Male & $\uparrow$ perlecan & [172] \\
\hline $\begin{array}{c}\text { Coarciation } \\
\text { [Sprague-Dawley Rats] }\end{array}$ & Aorta & Male & - (no change) in perlecan & [174] \\
\hline $\begin{array}{c} \pm \text { HELLP syndrome } \\
\text { [Human] } \\
\text { gestational age 28.4-39.7 } \\
\text { wk }\end{array}$ & Placenta & n. sp. & $\begin{array}{c}\downarrow \text { perlecan (MP4) during } \\
\text { placental maturation } \\
\uparrow \text { perlecan in early } \\
\text { pregnancy loss and in } \\
\text { preeclampsia without } \\
\text { HELLP } \\
\downarrow \text { perlecan in late } \\
\text { preeclampsia }\end{array}$ & [176] \\
\hline
\end{tabular}

Abbreviations. $\uparrow$ : increase; $\downarrow$ : decrease; -: no change; HELLP: hemolysis, elevated liver enzymes, and a low platelet count; n. sp.: not specified; SHRSP: spontaneously hypertensive stroke prone rats; wk: week.

\section{Conclusions}

Besides aging, atherosclerosis, hypertension, and diabetes are cerebrovascular risk factors for VCID, dementia and stroke, making it difficult to tease out the underlying mechanisms of cognitive decline. In addition, changes in perlecan expression and distribution in response to VCID appears to be injury, risk factor, location, sex, age, and perlecan domain dependent. Overall, great effort has been made in recent decades in understanding the role of perlecan in VCID. While recombinant perlecan DV, in mice and rats, has been found to be angiogenic, neuroprotective, and neuroreparative [17-19,68,157,178-180], new studies are warranted to address the role of perlecan and its domains in health and in combination with cerebrovascular risk factors.

Author Contributions: A.L.T., I.R., and I.J.B. performed literature searches and drafted the literature review. A.L.T., I.R., I.J.B., and G.J.B. revised and finalized the manuscript. All authors have read and agreed to the published version of the manuscript.

Funding: NIH R01NS089515 to G.J.B.

Conflicts of Interest: The authors have declared that no conflict of interest exists.

\section{References}

1. Hallmann, R.; Zhang, X.; Di Russo, J.; Li, L.; Song, J.; Hannocks, M.J.; Sorokin, L. The regulation of immune cell trafficking by the extracellular matrix. Curr. Opin. Cell Biol. 2015, 36, 54-61. [CrossRef] [PubMed]

2. Kalluri, R. Basement membranes: Structure, assembly and role in tumour angiogenesis. Nat. Rev. Cancer 2003, 3, 422-433. [CrossRef] [PubMed]

3. Xu, J.; Shi, G.P. Vascular wall extracellular matrix proteins and vascular diseases. Biochim. Biophys. Acta 2014, 1842, 2106-2119. [CrossRef] [PubMed] 
4. Engelhardt, B.; Sorokin, L. The blood-brain and the blood-cerebrospinal fluid barriers: Function and dysfunction. Semin. Immunopathol. 2009, 31, 497-511. [CrossRef]

5. Timpl, R. Structure and biological activity of basement membrane proteins. Eur. J. Biochem. 1989, 180, 487-502. [CrossRef]

6. Thomsen, M.S.; Routhe, L.J.; Moos, T. The vascular basement membrane in the healthy and pathological brain. J. Cereb. Blood Flow Metab. 2017, 37, 3300-3317. [CrossRef]

7. Morris, A.W.; Sharp, M.M.; Albargothy, N.J.; Fernandes, R.; Hawkes, C.A.; Verma, A.; Weller, R.O.; Carare, R.O. Vascular basement membranes as pathways for the passage of fluid into and out of the brain. Acta Neuropathol. 2016, 131, 725-736. [CrossRef]

8. Abbott, N.J.; Ronnback, L.; Hansson, E. Astrocyte-endothelial interactions at the blood-brain barrier. Nat. Rev. Neurosci. 2006, 7, 41-53. [CrossRef]

9. Engelhardt, B. beta1-integrin/matrix interactions support blood-brain barrier integrity. J. Cereb. Blood Flow Metab. 2011, 31, 1969-1971. [CrossRef]

10. Kallunki, P.; Eddy, R.L.; Byers, M.G.; Kestila, M.; Shows, T.B.; Tryggvason, K. Cloning of human heparan sulfate proteoglycan core protein, assignment of the gene (HSPG2) to 1 p36.1 $\rightarrow$ p35 and identification of a BamHI restriction fragment length polymorphism. Genomics 1991, 11, 389-396. [CrossRef]

11. Hassell, J.R.; Leyshon, W.C.; Ledbetter, S.R.; Tyree, B.; Suzuki, S.; Kato, M.; Kimata, K.; Kleinman, H.K. Isolation of two forms of basement membrane proteoglycans. J. Biol. Chem. 1985, 260, 8098-8105. [PubMed]

12. Iozzo, R.V.; Hassell, J.R. Identification of the precursor protein for the heparan sulfate proteoglycan of human colon carcinoma cells and its post-translational modifications. Arch. Biochem. Biophys. 1989, 269, 239-249. [CrossRef]

13. Murdoch, A.D.; Liu, B.; Schwarting, R.; Tuan, R.S.; Iozzo, R.V. Widespread expression of perlecan proteoglycan in basement membranes and extracellular matrices of human tissues as detected by a novel monoclonal antibody against domain III and by in situ hybridization. J. Histochem. Cytochem 1994, 42, 239-249. [CrossRef] [PubMed]

14. Whitelock, J.M.; Graham, L.D.; Melrose, J.; Murdoch, A.D.; Iozzo, R.V.; Underwood, P.A. Human perlecan immunopurified from different endothelial cell sources has different adhesive properties for vascular cells. Matrix Biol. 1999, 18, 163-178. [CrossRef]

15. Lord, M.S.; Chuang, C.Y.; Melrose, J.; Davies, M.J.; Iozzo, R.V.; Whitelock, J.M. The role of vascular-derived perlecan in modulating cell adhesion, proliferation and growth factor signaling. Matrix Biol. 2014, 35, 112-122. [CrossRef]

16. Lord, M.S.; Jung, M.; Cheng, B.; Whitelock, J.M. Transcriptional complexity of the HSPG2 gene in the human mast cell line, HMC-1. Matrix Biol. 2014, 35, 123-131. [CrossRef]

17. Parham, C.; Auckland, L.; Rachwal, J.; Clarke, D.; Bix, G. Perlecan domain V inhibits amyloid-beta induced brain endothelial cell toxicity and restoRes. angiogenic function. J. Alzheimers Dis. 2014, 38, 415-423. [CrossRef]

18. Lee, B.; Clarke, D.; Al Ahmad, A.; Kahle, M.; Parham, C.; Auckland, L.; Shaw, C.; Fidanboylu, M.; Orr, A.W.; Ogunshola, O.; et al. Perlecan domain V is neuroprotective and proangiogenic following ischemic stroke in rodents. J. Clin. Investig. 2011, 121, 3005-3023. [CrossRef]

19. Marcelo, A.; Bix, G. Investigating the role of perlecan domain V in post-ischemic cerebral angiogenesis. Methods Mol. Biol. 2014, 1135, 331-341.

20. Mongiat, M.; Sweeney, S.M.; San Antonio, J.D.; Fu, J.; Iozzo, R.V. Endorepellin, a novel inhibitor of angiogenesis derived from the C terminus of perlecan. J. Biol. Chem. 2003, 278, 4238-4249. [CrossRef]

21. Parham, C.L.; Shaw, C.; Auckland, L.D.; Dickeson, S.K.; Griswold-Prenner, I.; Bix, G. Perlecan Domain V Inhibits Amyloid-beta Induced Activation of the alpha2beta1 Integrin-Mediated Neurotoxic Signaling Cascade. J. Alzheimers Dis. 2016, 54, 1629-1647. [CrossRef] [PubMed]

22. Yurchenco, P.D.; Schittny, J.C. Molecular architecture of basement membranes. FASEB J. 1990, 4, 1577-1590. [CrossRef] [PubMed]

23. Yurchenco, P.D.; Patton, B.L. Developmental and pathogenic mechanisms of basement membrane assembly. Curr. Pharm. Des. 2009, 15, 1277-1294. [CrossRef] [PubMed]

24. Arikawa-Hirasawa, E.; Watanabe, H.; Takami, H.; Hassell, J.R.; Yamada, Y. Perlecan is essential for cartilage and cephalic development. Nat. Genet. 1999, 23, 354-358. [CrossRef] [PubMed] 
25. Costell, M.; Gustafsson, E.; Aszodi, A.; Morgelin, M.; Bloch, W.; Hunziker, E.; Addicks, K.; Timpl, R.; Fassler, R. Perlecan maintains the integrity of cartilage and some basement membranes. J. Cell Biol. 1999, 147, 1109-1122. [CrossRef] [PubMed]

26. Giros, A.; Morante, J.; Gil-Sanz, C.; Fairen, A.; Costell, M. Perlecan controls neurogenesis in the developing telencephalon. BMC Dev. Biol. 2007, 7, 29. [CrossRef]

27. Hassell, J.; Yamada, Y.; Arikawa-Hirasawa, E. Role of perlecan in skeletal development and diseases. Glycoconj. J. 2002, 19, 263-267. [CrossRef]

28. Graham, L.D.; Whitelock, J.M.; Underwood, P.A. Expression of human perlecan domain I as a recombinant heparan sulfate proteoglycan with 20-kDa glycosaminoglycan chains. Biochem. Biophys. Res. Commun. 1999, 256, 542-548. [CrossRef]

29. Hassell, J.R.; Robey, P.G.; Barrach, H.J.; Wilczek, J.; Rennard, S.I.; Martin, G.R. Isolation of a heparan sulfate-containing proteoglycan from basement membrane. Proc. Natl. Acad. Sci. USA 1980, 77, 4494-4498. [CrossRef]

30. Paulsson, M.; Yurchenco, P.D.; Ruben, G.C.; Engel, J.; Timpl, R. Structure of low density heparan sulfate proteoglycan isolated from a mouse tumor basement membrane. J. Mol. Biol. 1987, 197, 297-313. [CrossRef]

31. Martinez, J.R.; Dhawan, A.; Farach-Carson, M.C. Modular Proteoglycan Perlecan/HSPG2: Mutations, Phenotypes, and Functions. Genes 2018, 9, 556. [CrossRef] [PubMed]

32. Gubbiotti, M.A.; Neill, T.; Iozzo, R.V. A current view of perlecan in physiology and pathology: A mosaic of functions. Matrix Biol. 2017, 57, 285-298. [CrossRef] [PubMed]

33. Dolan, M.; Horchar, T.; Rigatti, B.; Hassell, J.R. Identification of sites in domain I of perlecan that regulate heparan sulfate synthesis. J. Biol. Chem. 1997, 272, 4316-4322. [CrossRef] [PubMed]

34. Bork, P.; Patthy, L. The SEA module: A new extracellular domain associated with O-glycosylation. Protein Sci. 1995, 4, 1421-1425. [CrossRef]

35. Lord, M.S.; Ellis, A.L.; Farrugia, B.L.; Whitelock, J.M.; Grenett, H.; Li, C.; O'Grady, R.L.; DeCarlo, A.A. Perlecan and vascular endothelial growth factor-encoding DNA-loaded chitosan scaffolds promote angiogenesis and wound healing. J. Control. Release 2017, 250, 48-61. [CrossRef]

36. Murdoch, A.D.; Dodge, G.R.; Cohen, I.; Tuan, R.S.; Iozzo, R.V. Primary structure of the human heparan sulfate proteoglycan from basement membrane (HSPG2/perlecan). A chimeric molecule with multiple domains homologous to the low density lipoprotein receptor, laminin, neural cell adhesion molecules, and epidermal growth factor. J. Biol. Chem. 1992, 267, 8544-8557.

37. Sasse, P.; Malan, D.; Fleischmann, M.; Roell, W.; Gustafsson, E.; Bostani, T.; Fan, Y.; Kolbe, T.; Breitbach, M.; Addicks, K.; et al. Perlecan is critical for heart stability. Cardiovasc. Res. 2008, 80, 435-444. [CrossRef]

38. Tsumaki, N.; Tanaka, K.; Arikawa-Hirasawa, E.; Nakase, T.; Kimura, T.; Thomas, J.T.; Ochi, T.; Luyten, F.P.; Yamada, Y. Role of CDMP-1 in skeletal morphogenesis: Promotion of mesenchymal cell recruitment and chondrocyte differentiation. J. Cell Biol. 1999, 144, 161-173. [CrossRef]

39. Xu, Z.; Ichikawa, N.; Kosaki, K.; Yamada, Y.; Sasaki, T.; Sakai, L.Y.; Kurosawa, H.; Hattori, N.; Arikawa-Hirasawa, E. Perlecan deficiency causes muscle hypertrophy, a decrease in myostatin expression, and changes in muscle fiber composition. Matrix Biol. 2010, 29, 461-470. [CrossRef]

40. Nakamura, K.; Ikeuchi, T.; Nara, K.; Rhodes, C.S.; Zhang, P.; Chiba, Y.; Kazuno, S.; Miura, Y.; Ago, T.; Arikawa-Hirasawa, E.; et al. Perlecan regulates pericyte dynamics in the maintenance and repair of the blood-brain barrier. J. Cell Biol. 2019, 218, 3506-3525. [CrossRef]

41. Kerever, A.; Mercier, F.; Nonaka, R.; de Vega, S.; Oda, Y.; Zalc, B.; Okada, Y.; Hattori, N.; Yamada, Y.; Arikawa-Hirasawa, E. Perlecan is required for FGF-2 signaling in the neural stem cell niche. Stem Cell Res. 2014, 12, 492-505. [CrossRef] [PubMed]

42. Nonaka, R.; Iesaki, T.; de Vega, S.; Daida, H.; Okada, T.; Sasaki, T.; Arikawa-Hirasawa, E. Perlecan deficiency causes endothelial dysfunction by reducing the expression of endothelial nitric oxide synthase. Physiol. Rep. 2015, 3. [CrossRef] [PubMed]

43. Rossi, M.; Morita, H.; Sormunen, R.; Airenne, S.; Kreivi, M.; Wang, L.; Fukai, N.; Olsen, B.R.; Tryggvason, K.; Soininen, R. Heparan sulfate chains of perlecan are indispensable in the lens capsule but not in the kidney. EMBO J. 2003, 22, 236-245. [CrossRef] [PubMed]

44. Tran, P.K.; Tran-Lundmark, K.; Soininen, R.; Tryggvason, K.; Thyberg, J.; Hedin, U. Increased intimal hyperplasia and smooth muscle cell proliferation in transgenic mice with heparan sulfate-deficient perlecan. Circ. Res. 2004, 94, 550-558. [CrossRef] 
45. Cohen, I.R.; Grassel, S.; Murdoch, A.D.; Iozzo, R.V. Structural characterization of the complete human perlecan gene and its promoter. Proc. Natl. Acad. Sci. USA 1993, 90, 10404-10408. [CrossRef] [PubMed]

46. Costell, M.; Sasaki, T.; Mann, K.; Yamada, Y.; Timpl, R. Structural characterization of recombinant domain II of the basement membrane proteoglycan perlecan. FEBS Lett. 1996, 396, 127-131. [CrossRef]

47. Noonan, D.M.; Hassell, J.R. Perlecan, the large low-density proteoglycan of basement membranes: Structure and variant forms. Kidney Int. 1993, 43, 53-60. [CrossRef] [PubMed]

48. Noonan, D.M.; Fulle, A.; Valente, P.; Cai, S.; Horigan, E.; Sasaki, M.; Yamada, Y.; Hassell, J.R. The complete sequence of perlecan, a basement membrane heparan sulfate proteoglycan, reveals extensive similarity with laminin A chain, low density lipoprotein-receptor, and the neural cell adhesion molecule. J. Biol. Chem. 1991, 266, 22939-22947.

49. Schulze, B.; Mann, K.; Battistutta, R.; Wiedemann, H.; Timpl, R. Structural properties of recombinant domain III-3 of perlecan containing a globular domain inserted into an epidermal-growth-factor-like motif. Eur. J. Biochem. 1995, 231, 551-556. [CrossRef]

50. Smith, S.M.; West, L.A.; Hassell, J.R. The core protein of growth plate perlecan binds FGF-18 and alters its mitogenic effect on chondrocytes. Arch. Biochem. Biophys. 2007, 468, 244-251. [CrossRef]

51. Nugent, M.A.; Nugent, H.M.; Iozzo, R.V.; Sanchack, K.; Edelman, E.R. Perlecan is required to inhibit thrombosis after deep vascular injury and contributes to endothelial cell-mediated inhibition of intimal hyperplasia. Proc. Natl. Acad. Sci. USA 2000, 97, 6722-6727. [CrossRef] [PubMed]

52. Rodgers, K.D.; Sasaki, T.; Aszodi, A.; Jacenko, O. Reduced perlecan in mice results in chondrodysplasia resembling Schwartz-Jampel syndrome. Hum. Mol. Genet. 2007, 16, 515-528. [CrossRef] [PubMed]

53. Nicole, S.; Davoine, C.S.; Topaloglu, H.; Cattolico, L.; Barral, D.; Beighton, P.; Hamida, C.B.; Hammouda, H.; Cruaud, C.; White, P.S.; et al. Perlecan, the major proteoglycan of basement membranes, is altered in patients with Schwartz-Jampel syndrome (chondrodystrophic myotonia). Nat. Genet. 2000, 26, 480-483. [CrossRef] [PubMed]

54. Stum, M.; Davoine, C.S.; Vicart, S.; Guillot-Noel, L.; Topaloglu, H.; Carod-Artal, FJ.; Kayserili, H.; Hentati, F.; Merlini, L.; Urtizberea, J.A.; et al. Spectrum of HSPG2 (Perlecan) mutations in patients with Schwartz-Jampel syndrome. Hum. Mutat. 2006, 27, 1082-1091. [CrossRef]

55. Arikawa-Hirasawa, E.; Wilcox, W.R.; Le, A.H.; Silverman, N.; Govindraj, P.; Hassell, J.R.; Yamada, Y. Dyssegmental dysplasia, Silverman-Handmaker type, is caused by functional null mutations of the perlecan gene. Nat. Genet. 2001, 27, 431-434. [CrossRef]

56. Iwata, S.; Ito, M.; Nakata, T.; Noguchi, Y.; Okuno, T.; Ohkawara, B.; Masuda, A.; Goto, T.; Adachi, M.; Osaka, H.; et al. A missense mutation in domain III in HSPG2 in Schwartz-Jampel syndrome compromises secretion of perlecan into the extracellular space. Neuromuscul. Disord. 2015, 25, 667-671. [CrossRef]

57. Bauche, S.; Boerio, D.; Davoine, C.S.; Bernard, V.; Stum, M.; Bureau, C.; Fardeau, M.; Romero, N.B.; Fontaine, B.; Koenig, J.; et al. Peripheral nerve hyperexcitability with preterminal nerve and neuromuscular junction remodeling is a hallmark of Schwartz-Jampel syndrome. Neuromuscul. Disord. 2013, 23, 998-1009. [CrossRef]

58. Arikawa-Hirasawa, E.; Le, A.H.; Nishino, I.; Nonaka, I.; Ho, N.C.; Francomano, C.A.; Govindraj, P.; Hassell, J.R.; Devaney, J.M.; Spranger, J.; et al. Structural and functional mutations of the perlecan gene cause Schwartz-Jampel syndrome, with myotonic myopathy and chondrodysplasia. Am. J. Hum. Genet. 2002, 70 , 1368-1375. [CrossRef]

59. Rieubland, C.; Jacquemont, S.; Mittaz, L.; Osterheld, M.C.; Vial, Y.; Superti-Furga, A.; Unger, S.; Bonafe, L. Phenotypic and molecular characterization of a novel case of dyssegmental dysplasia, Silverman-Handmaker type. Eur. J. Med. Genet. 2010, 53, 294-298. [CrossRef]

60. Das Bhowmik, A.; Dalal, A.; Matta, D.; Kandadai, R.M.; Kanikannan, M.A.; Aggarwal, S. Identification of a novel splice site HSPG2 mutation and prenatal diagnosis in Schwartz Jampel Syndrome type 1 using whole exome sequencing. Neuromuscul. Disord. 2016, 26, 809-814. [CrossRef]

61. Roberts, J.; Kahle, M.P.; Bix, G.J. Perlecan and the blood-brain barrier: Beneficial proteolysis? Front. Pharmacol. 2012, 3, 155. [CrossRef] [PubMed]

62. Hopf, M.; Gohring, W.; Kohfeldt, E.; Yamada, Y.; Timpl, R. Recombinant domain IV of perlecan binds to nidogens, laminin-nidogen complex, fibronectin, fibulin-2 and heparin. Eur. J. Biochem. 1999, 259, 917-925. [CrossRef] [PubMed] 
63. Fukuda, S.; Fini, C.A.; Mabuchi, T.; Koziol, J.A.; Eggleston, L.L., Jr.; del Zoppo, G.J. Focal cerebral ischemia induces active proteases that degrade microvascular matrix. Stroke 2004, 35, 998-1004. [CrossRef] [PubMed]

64. Arpino, V.; Brock, M.; Gill, S.E. The role of TIMPs in regulation of extracellular matrix proteolysis. Matrix Biol. 2015, 44, 247-254. [CrossRef] [PubMed]

65. Saini, M.G.; Bix, G.J. Oxygen-glucose deprivation (OGD) and interleukin-1 (IL-1) differentially modulate cathepsin B/L mediated generation of neuroprotective perlecan LG3 by neurons. Brain Res. 2012, 1438, 65-74. [CrossRef]

66. Gonzalez, E.M.; Reed, C.C.; Bix, G.; Fu, J.; Zhang, Y.; Gopalakrishnan, B.; Greenspan, D.S.; Iozzo, R.V. BMP-1/Tolloid-like metalloproteases process endorepellin, the angiostatic C-terminal fragment of perlecan. J. Biol. Chem. 2005, 280, 7080-7087. [CrossRef]

67. Jung, M.; Lord, M.S.; Cheng, B.; Lyons, J.G.; Alkhouri, H.; Hughes, J.M.; McCarthy, S.J.; Iozzo, R.V.; Whitelock, J.M. Mast cells produce novel shorter forms of perlecan that contain functional endorepellin: A role in angiogenesis and wound healing. J. Biol. Chem. 2013, 288, 3289-3304. [CrossRef]

68. Wright, S.; Parham, C.; Lee, B.; Clarke, D.; Auckland, L.; Johnston, J.; Lawrence, A.L.; Dickeson, S.K.; Santoro, S.A.; Griswold-Prenner, I.; et al. Perlecan domain V inhibits alpha2 integrin-mediated amyloid-beta neurotoxicity. NeuroBiol. Aging 2012, 33, 1379-1388. [CrossRef]

69. Saku, T.; Furthmayr, H. Characterization of the major heparan sulfate proteoglycan secreted by bovine aortic endothelial cells in culture. Homology to the large molecular weight molecule of basement membranes. J. Biol. Chem. 1989, 264, 3514-3523.

70. Zhang, W.; Chuang, Y.J.; Swanson, R.; Li, J.; Seo, K.; Leung, L.; Lau, L.F.; Olson, S.T. Antiangiogenic antithrombin down-regulates the expression of the proangiogenic heparan sulfate proteoglycan, perlecan, in endothelial cells. Blood 2004, 103, 1185-1191. [CrossRef]

71. Kojima, T.; Leone, C.W.; Marchildon, G.A.; Marcum, J.A.; Rosenberg, R.D. Isolation and characterization of heparan sulfate proteoglycans produced by cloned rat microvascular endothelial cells. J. Biol. Chem. 1992, $267,4859-4869$.

72. Forsten, K.E.; Courant, N.A.; Nugent, M.A. Endothelial proteoglycans inhibit bFGF binding and mitogenesis. J. Cell. Physiol. 1997, 172, 209-220. [CrossRef]

73. Stratman, A.N.; Malotte, K.M.; Mahan, R.D.; Davis, M.J.; Davis, G.E. Pericyte recruitment during vasculogenic tube assembly stimulates endothelial basement membrane matrix formation. Blood 2009, 114, 5091-5101. [CrossRef]

74. Saikia, P.; Thangavadivel, S.; Medeiros, C.S.; Lassance, L.; de Oliveira, R.C.; Wilson, S.E. IL-1 and TGF-beta Modulation of Epithelial Basement Membrane Components Perlecan and Nidogen Production by Corneal Stromal Cells. Investig. Ophthalmol. Vis. Sci. 2018, 59, 5589-5598. [CrossRef]

75. Garcia de Yebenes, E.; Ho, A.; Damani, T.; Fillit, H.; Blum, M. Regulation of the heparan sulfate proteoglycan, perlecan, by injury and interleukin-1alpha. J. Neurochem. 1999, 73, 812-820. [CrossRef] [PubMed]

76. Santos-Silva, A.; Fairless, R.; Frame, M.C.; Montague, P.; Smith, G.M.; Toft, A.; Riddell, J.S.; Barnett, S.C. FGF/heparin differentially regulates Schwann cell and olfactory ensheathing cell interactions with astrocytes: A role in astrocytosis. J. Neurosci. 2007, 27, 7154-7167. [CrossRef] [PubMed]

77. Goyal, A.; Pal, N.; Concannon, M.; Paul, M.; Doran, M.; Poluzzi, C.; Sekiguchi, K.; Whitelock, J.M.; Neill, T.; Iozzo, R.V. Endorepellin, the angiostatic module of perlecan, interacts with both the alpha2beta1 integrin and vascular endothelial growth factor receptor 2 (VEGFR2): A dual receptor antagonism. J. Biol. Chem. 2011, 286, 25947-25962. [CrossRef]

78. O’Brien, K.D.; McDonald, T.O.; Kunjathoor, V.; Eng, K.; Knopp, E.A.; Lewis, K.; Lopez, R.; Kirk, E.A.; Chait, A.; Wight, T.N.; et al. Serum amyloid A and lipoprotein retention in murine models of atherosclerosis. Arterioscler. Thromb. Vasc. Biol. 2005, 25, 785-790. [CrossRef] [PubMed]

79. Kunjathoor, V.V.; Chiu, D.S.; O'Brien, K.D.; LeBoeuf, R.C. Accumulation of biglycan and perlecan, but not versican, in lesions of murine models of atherosclerosis. Arterioscler. Thromb. Vasc. Biol. 2002, 22, 462-468. [CrossRef] [PubMed]

80. Hollmann, J.; Schmidt, A.; von Bassewitz, D.B.; Buddecke, E. Relationship of sulfated glycosaminoglycans and cholesterol content in normal and arteriosclerotic human aorta. Arteriosclerosis 1989, 9, 154-158. [CrossRef]

81. Huang, F.; Thompson, J.C.; Wilson, P.G.; Aung, H.H.; Rutledge, J.C.; Tannock, L.R. Angiotensin II increases vascular proteoglycan content preceding and contributing to atherosclerosis development. J. Lipid Res. 2008, 49, 521-530. [CrossRef] [PubMed] 
82. Tang, T.; Thompson, J.C.; Wilson, P.G.; Yoder, M.H.; Mueller, J.; Fischer, J.W.; Williams, K.J.; Tannock, L.R. Biglycan deficiency: Increased aortic aneurysm formation and lack of atheroprotection. J. Mol. Cell. Cardiol. 2014, 75, 174-180. [CrossRef] [PubMed]

83. Tran-Lundmark, K.; Tran, P.K.; Paulsson-Berne, G.; Friden, V.; Soininen, R.; Tryggvason, K.; Wight, T.N.; Kinsella, M.G.; Boren, J.; Hedin, U. Heparan sulfate in perlecan promotes mouse atherosclerosis: Roles in lipid permeability, lipid retention, and smooth muscle cell proliferation. Circ. Res. 2008, 103, 43-52. [CrossRef]

84. Tran, P.K.; Agardh, H.E.; Tran-Lundmark, K.; Ekstrand, J.; Roy, J.; Henderson, B.; Gabrielsen, A.; Hansson, G.K.; Swedenborg, J.; Paulsson-Berne, G.; et al. Reduced perlecan expression and accumulation in human carotid atherosclerotic lesions. Atherosclerosis 2007, 190, 264-270. [CrossRef] [PubMed]

85. Kochanek, K.D.; Murphy, S.L.; Xu, J.; Arias, E. Deaths: Final Data for 2017. Natl. Vital. Stat Rep. 2019, 68, 1-77. Available online: https://www.cdc.gov/nchs/ (accessed on 20 January 2020).

86. Jani, B.; Rajkumar, C. Ageing and vascular ageing. Postgrad. Med. J. 2006, 82, 357-362. [CrossRef]

87. Wang, X.; Khalil, R.A. Matrix Metalloproteinases, Vascular Remodeling, and Vascular Disease. Adv. Pharmacol. 2018, 81, 241-330.

88. Hawkes, C.A.; Hartig, W.; Kacza, J.; Schliebs, R.; Weller, R.O.; Nicoll, J.A.; Carare, R.O. Perivascular drainage of solutes is impaired in the ageing mouse brain and in the presence of cerebral amyloid angiopathy. Acta Neuropathol. 2011, 121, 431-443. [CrossRef]

89. Kerever, A.; Yamada, T.; Suzuki, Y.; Mercier, F.; Arikawa-Hirasawa, E. Fractone aging in the subventricular zone of the lateral ventricle. J. Chem. Neuroanat. 2015, 66, 52-60. [CrossRef]

90. Kalaria, R.N. Vascular basis for brain degeneration: Faltering controls and risk factors for dementia. Nutr. Rev. 2010, 68 (Suppl. 2), S74-S87. [CrossRef]

91. Debette, S.; Seshadri, S.; Beiser, A.; Au, R.; Himali, J.J.; Palumbo, C.; Wolf, P.A.; DeCarli, C. Midlife vascular risk factor exposure accelerates structural brain aging and cognitive decline. Neurology 2011, 77, 461-468. [CrossRef]

92. Murray, I.V.; Proza, J.F.; Sohrabji, F.; Lawler, J.M. Vascular and metabolic dysfunction in Alzheimer's disease: A review. Exp. Biol. Med. 2011, 236, 772-782. [CrossRef] [PubMed]

93. Rodrigue, K.M. Contribution of cerebrovascular health to the diagnosis of Alzheimer disease. JAMA Neurol. 2013, 70, 438-439. [CrossRef] [PubMed]

94. Montagne, A.; Barnes, S.R.; Sweeney, M.D.; Halliday, M.R.; Sagare, A.P.; Zhao, Z.; Toga, A.W.; Jacobs, R.E.; Liu, C.Y.; Amezcua, L.; et al. Blood-brain barrier breakdown in the aging human hippocampus. Neuron 2015, 85, 296-302. [CrossRef]

95. Wang, L.; Du, Y.; Wang, K.; Xu, G.; Luo, S.; He, G. Chronic cerebral hypoperfusion induces memory deficits and facilitates Abeta generation in C57BL/6J mice. Exp. Neurol. 2016, 283, 353-364. [CrossRef] [PubMed]

96. Hilal, S.; Tan, C.S.; van Veluw, S.J.; Xu, X.; Vrooman, H.; Tan, B.Y.; Venketasubramanian, N.; Biessels, G.J.; Chen, C. Cortical cerebral microinfarcts predict cognitive decline in memory clinic patients. J. Cereb. Blood Flow Metab. 2019. [CrossRef]

97. Fulop, G.; Tarantini, S.; Yabluchanskiy, A.; Molnar, A.; Prodan, C.; Kiss, T.; Csipo, T.; Lipecz, A.; Balasubramanian, P.; Farkas, E.; et al. Role of age-related alterations of the cerebral venous circulation in the pathogenesis of vascular cognitive impairment. Am. J. Physiol. Heart Circ. Physiol. 2019. [CrossRef]

98. Mozaffarian, D.; Benjamin, E.J.; Go, A.S.; Arnett, D.K.; Blaha, M.J.; Cushman, M.; de Ferranti, S.; Despres, J.P.; Fullerton, H.J.; Howard, V.J.; et al. Heart disease and stroke statistics—2015 update: A report from the American Heart Association. Circulation 2015, 131. [CrossRef]

99. Bouras, C.; Kovari, E.; Herrmann, F.R.; Rivara, C.B.; Bailey, T.L.; von Gunten, A.; Hof, P.R.; Giannakopoulos, P. Stereologic analysis of microvascular morphology in the elderly: Alzheimer disease pathology and cognitive status. J. Neuropathol. Exp. Neurol. 2006, 65, 235-244. [CrossRef]

100. Donnan, G.A.; Fisher, M.; Macleod, M.; Davis, S.M. Stroke. Lancet 2008, 371, 1612-1623. [CrossRef]

101. Taylor, C.A.; Greenlund, S.F.; McGuire, L.C.; Lu, H.; Croft, J.B. Deaths from Alzheimer's Disease-United States, 1999-2014. Morb. Mortal. Wkly. Rep. 2017, 66, 521-526. [CrossRef] [PubMed]

102. Tong, X.K.; Nicolakakis, N.; Kocharyan, A.; Hamel, E. Vascular remodeling versus amyloid beta-induced oxidative stress in the cerebrovascular dysfunctions associated with Alzheimer's disease. J. Neurosci. 2005, 25, 11165-11174. [CrossRef] [PubMed] 
103. Zarow, C.; Barron, E.; Chui, H.C.; Perlmutter, L.S. Vascular basement membrane pathology and Alzheimer's disease. Ann. N. Y. Acad. Sci. 1997, 826, 147-160. [CrossRef] [PubMed]

104. Rockenstein, E.; Adame, A.; Mante, M.; Larrea, G.; Crews, L.; Windisch, M.; Moessler, H.; Masliah, E. Amelioration of the cerebrovascular amyloidosis in a transgenic model of Alzheimer's disease with the neurotrophic compound cerebrolysin. J. Neural Transm. 2005, 112, 269-282. [CrossRef] [PubMed]

105. Thal, D.R.; Capetillo-Zarate, E.; Larionov, S.; Staufenbiel, M.; Zurbruegg, S.; Beckmann, N. Capillary cerebral amyloid angiopathy is associated with vessel occlusion and cerebral blood flow disturbances. Neurobiol. Aging 2009, 30, 1936-1948. [CrossRef] [PubMed]

106. de Montgolfier, O.; Pouliot, P.; Gillis, M.A.; Ferland, G.; Lesage, F.; Thorin-Trescases, N.; Thorin, E. Systolic hypertension-induced neurovascular unit disruption magnifies vascular cognitive impairment in middle-age atherosclerotic LDLr(-/-):hApoB(+/+) mice. Geroscience 2019. [CrossRef]

107. Cheng, G.; Huang, C.; Deng, H.; Wang, H. Diabetes as a risk factor for dementia and mild cognitive impairment: A meta-analysis of longitudinal studies. Intern. Med. J. 2012, 42, 484-491. [CrossRef]

108. de la Monte, S.M. Relationships between diabetes and cognitive impairment. Endocrinol. Metab. Clin. North Am. 2014, 43, 245-267. [CrossRef]

109. de la Monte, S.M.; Tong, M.; Wands, J.R. The 20-Year Voyage Aboard the Journal of Alzheimer's Disease: Docking at 'Type 3 Diabetes', Environmental/Exposure Factors, Pathogenic Mechanisms, and Potential Treatments. J. Alzheimers Dis. 2018, 62, 1381-1390. [CrossRef]

110. Profenno, L.A.; Porsteinsson, A.P.; Faraone, S.V. Meta-analysis of Alzheimer's disease risk with obesity, diabetes, and related disorders. Biol. Psychiatry 2010, 67, 505-512. [CrossRef]

111. Toro, P.; Schonknecht, P.; Schroder, J. Type II diabetes in mild cognitive impairment and Alzheimer's disease: Results from a prospective population-based study in Germany. J. Alzheimers Dis. 2009, 16, 687-691. [CrossRef] [PubMed]

112. Wang, K.C.; Woung, L.C.; Tsai, M.T.; Liu, C.C.; Su, Y.H.; Li, C.Y. Risk of Alzheimer's disease in relation to diabetes: A population-based cohort study. Neuroepidemiology 2012, 38, 237-244. [CrossRef] [PubMed]

113. Zhang, J.; Chen, C.; Hua, S.; Liao, H.; Wang, M.; Xiong, Y.; Cao, F. An updated meta-analysis of cohort studies: Diabetes and risk of Alzheimer's disease. Diabetes Res. Clin. Pract. 2017, 124, 41-47. [CrossRef] [PubMed]

114. Livingston, G.; Sommerlad, A.; Orgeta, V.; Costafreda, S.G.; Huntley, J.; Ames, D.; Ballard, C.; Banerjee, S.; Burns, A.; Cohen-Mansfield, J.; et al. Dementia prevention, intervention, and care. Lancet 2017, 390, 2673-2734. [CrossRef]

115. Sandoval, K.E.; Witt, K.A. Blood-brain barrier tight junction permeability and ischemic stroke. NeuroBiol. Dis. 2008, 32, 200-219. [CrossRef] [PubMed]

116. Anthony, D.C.; Ferguson, B.; Matyzak, M.K.; Miller, K.M.; Esiri, M.M.; Perry, V.H. Differential matrix metalloproteinase expression in cases of multiple sclerosis and stroke. Neuropathol. Appl. NeuroBiol. 1997, 23, 406-415. [CrossRef]

117. Clark, A.W.; Krekoski, C.A.; Bou, S.S.; Chapman, K.R.; Edwards, D.R. Increased gelatinase A (MMP-2) and gelatinase B (MMP-9) activities in human brain after focal ischemia. Neurosci. Lett. 1997, 238, 53-56. [CrossRef]

118. Rosenberg, G.A.; Sullivan, N.; Esiri, M.M. White matter damage is associated with matrix metalloproteinases in vascular dementia. Stroke 2001, 32, 1162-1168. [CrossRef]

119. Newby, A.C.; Zaltsman, A.B. Fibrous cap formation or destruction-The critical importance of vascular smooth muscle cell proliferation, migration and matrix formation. Cardiovasc. Res. 1999, 41, 345-360. [CrossRef]

120. Njoto, I.; Kalim, H.; Soeatmadji, D.W.; Handono, K.; Fatchiyah, F. Effect of Hyperglycemia to The mRNA Level and Protein Expression of Perlecan at Rat Model of Osteoarthritis with Diabetes Mellitus Type 1. Med. Arch. 2019, 73, 144-148. [CrossRef]

121. Reine, T.M.; Grondahl, F.; Jenssen, T.G.; Hadler-Olsen, E.; Prydz, K.; Kolset, S.O. Reduced sulfation of chondroitin sulfate but not heparan sulfate in kidneys of diabetic $\mathrm{db} / \mathrm{db}$ mice. J. Histochem. Cytochem. 2013, 61, 606-616. [CrossRef] [PubMed]

122. Yung, S.; Chau, M.K.; Zhang, Q.; Zhang, C.Z.; Chan, T.M. Sulodexide decreases albuminuria and regulates matrix protein accumulation in C57BL/6 mice with streptozotocin-induced type I diabetic nephropathy. PLoS ONE 2013, 8, e54501. [CrossRef] [PubMed] 
123. Gambaro, G.; Venturini, A.P.; Noonan, D.M.; Fries, W.; Re, G.; Garbisa, S.; Milanesi, C.; Pesarini, A.; Borsatti, A.; Marchi, E.; et al. Treatment with a glycosaminoglycan formulation ameliorates experimental diabetic nephropathy. Kidney Int. 1994, 46, 797-806. [CrossRef] [PubMed]

124. Ebara, T.; Conde, K.; Kako, Y.; Liu, Y.; Xu, Y.; Ramakrishnan, R.; Goldberg, I.J.; Shachter, N.S. Delayed catabolism of apoB-48 lipoproteins due to decreased heparan sulfate proteoglycan production in diabetic mice. J. Clin. Investig. 2000, 105, 1807-1818. [CrossRef] [PubMed]

125. Mooyaart, A.L.; Valk, E.J.; van Es, L.A.; Bruijn, J.A.; de Heer, E.; Freedman, B.I.; Dekkers, O.M.; Baelde, H.J. Genetic associations in diabetic nephropathy: A meta-analysis. Diabetologia 2011, 54, 544-553. [CrossRef] [PubMed]

126. Chan, G.C.; Eng, D.G.; Miner, J.H.; Alpers, C.E.; Hudkins, K.L.; Chang, A.; Pippin, J.W.; Shankland, S.J. Differential Expression of Parietal Epithelial Cell and Podocyte Extracellular Matrix Proteins in Focal Segmental Glomerulosclerosis and Diabetic Nephropathy. Am. J. Physiol. Renal Physiol. 2019. [CrossRef]

127. Kriz, W.; Lowen, J.; Federico, G.; van den Born, J.; Grone, E.; Grone, H.J. Accumulation of worn-out GBM material substantially contributes to mesangial matrix expansion in diabetic nephropathy. Am. J. Physiol. Renal Physiol. 2017, 312, F1101-F1111. [CrossRef]

128. Menne, J.; Park, J.K.; Shushakova, N.; Mengel, M.; Meier, M.; Fliser, D. The continuous erythropoietin receptor activator affects different pathways of diabetic renal injury. J. Am. Soc. Nephrol. 2007, 18, 2046-2053. [CrossRef] [PubMed]

129. Hansen, P.M.; Chowdhury, T.; Deckert, T.; Hellgren, A.; Bain, S.C.; Pociot, F. Genetic variation of the heparan sulfate proteoglycan gene (perlecan gene). Association with urinary albumin excretion in IDDM patients. Diabetes 1997, 46, 1658-1659. [CrossRef]

130. Ljubimov, A.V.; Burgeson, R.E.; Butkowski, R.J.; Couchman, J.R.; Zardi, L.; Ninomiya, Y.; Sado, Y.; Huang, Z.S.; Nesburn, A.B.; Kenney, M.C. Basement membrane abnormalities in human eyes with diabetic retinopathy. J. Histochem. Cytochem. 1996, 44, 1469-1479. [CrossRef]

131. Reine, T.M.; Kusche-Gullberg, M.; Feta, A.; Jenssen, T.; Kolset, S.O. Heparan sulfate expression is affected by inflammatory stimuli in primary human endothelial cells. Glycoconj. J. 2012, 29, 67-76. [CrossRef] [PubMed]

132. Holderied, A.; Romoli, S.; Eberhard, J.; Konrad, L.A.; Devarapu, S.K.; Marschner, J.A.; Muller, S.; Anders, H.J. Glomerular parietal epithelial cell activation induces collagen secretion and thickening of Bowman's capsule in diabetes. Lab. Investig. 2015, 95, 273-282. [CrossRef] [PubMed]

133. Chang, S.C.; Vivian Yang, W.C. Hyperglycemia induces altered expressions of angiogenesis associated molecules in the trophoblast. Evid. Based Complement. Altern. Med. 2013, 2013, 457971. [CrossRef] [PubMed]

134. Yang, W.C.; Su, T.H.; Yang, Y.C.; Chang, S.C.; Chen, C.Y.; Chen, C.P. Altered perlecan expression in placental development and gestational diabetes mellitus. Placenta 2005, 26, 780-788. [CrossRef] [PubMed]

135. Otsuka, F.; Kramer, M.C.; Woudstra, P.; Yahagi, K.; Ladich, E.; Finn, A.V.; de Winter, R.J.; Kolodgie, F.D.; Wight, T.N.; Davis, H.R.; et al. Natural progression of atherosclerosis from pathologic intimal thickening to late fibroatheroma in human coronary arteries: A pathology study. Atherosclerosis 2015, 241, 772-782. [CrossRef]

136. Nakashima, Y.; Wight, T.N.; Sueishi, K. Early atherosclerosis in humans: Role of diffuse intimal thickening and extracellular matrix proteoglycans. Cardiovasc. Res. 2008, 79, 14-23. [CrossRef]

137. Virmani, R.; Kolodgie, F.D.; Burke, A.P.; Farb, A.; Schwartz, S.M. Lessons from sudden coronary death: A comprehensive morphological classification scheme for atherosclerotic lesions. Arterioscler. Thromb. Vasc. Biol. 2000, 20, 1262-1275. [CrossRef]

138. Virmani, R.; Kolodgie, F.D.; Burke, A.P.; Finn, A.V.; Gold, H.K.; Tulenko, T.N.; Wrenn, S.P.; Narula, J. Atherosclerotic plaque progression and vulnerability to rupture: Angiogenesis as a source of intraplaque hemorrhage. Arterioscler. Thromb. Vasc. Biol. 2005, 25, 2054-2061. [CrossRef]

139. Evanko, S.P.; Raines, E.W.; Ross, R.; Gold, L.I.; Wight, T.N. Proteoglycan distribution in lesions of atherosclerosis depends on lesion severity, structural characteristics, and the proximity of platelet-derived growth factor and transforming growth factor-beta. Am. J. Pathol. 1998, 152, 533-546.

140. Murata, K.; Murata, A.; Yoshida, K. Heparan sulfate isomers in cerebral arteries of Japanese women with aging and with atherosclerosis-Heparitinase and high-performance liquid chromatography determinations. Atherosclerosis 1997, 132, 9-17. [CrossRef]

141. Vikramadithyan, R.K.; Kako, Y.; Chen, G.; Hu, Y.; Arikawa-Hirasawa, E.; Yamada, Y.; Goldberg, I.J. Atherosclerosis in perlecan heterozygous mice. J. Lipid Res. 2004, 45, 1806-1812. [CrossRef] [PubMed] 
142. Wasty, F.; Alavi, M.Z.; Moore, S. Distribution of glycosaminoglycans in the intima of human aortas: Changes in atherosclerosis and diabetes mellitus. Diabetologia 1993, 36, 316-322. [CrossRef] [PubMed]

143. Wang, B.; Jin, F.; Yang, Z.; Lu, Z.; Zheng, C.; Wang, L. HSPG2 gene C/A polymorphism does not confer susceptibility to Alzheimer's disease in Chinese. Dement. Geriatr. Cogn. Disord. 2007, 23, 312-315. [CrossRef] [PubMed]

144. Engelberg, H. Endogenous heparin activity deficiency: The 'missing link' in atherogenesis? Atherosclerosis 2001, 159, 253-260. [CrossRef]

145. Pillarisetti, S. Lipoprotein modulation of subendothelial heparan sulfate proteoglycans (perlecan) and atherogenicity. Trends Cardiovasc. Med. 2000, 10, 60-65. [CrossRef]

146. Duan, W.; Paka, L.; Pillarisetti, S. Distinct effects of glucose and glucosamine on vascular endothelial and smooth muscle cells: Evidence for a protective role for glucosamine in atherosclerosis. Cardiovasc. Diabetol. 2005, 4, 16. [CrossRef]

147. Smith, E.E.; Greenberg, S.M. Beta-amyloid, blood vessels, and brain function. Stroke 2009, 40, $2601-2606$. [CrossRef]

148. Palmqvist, S.; Scholl, M.; Strandberg, O.; Mattsson, N.; Stomrud, E.; Zetterberg, H.; Blennow, K.; Landau, S.; Jagust, W.; Hansson, O. Earliest accumulation of beta-amyloid occurs within the default-mode network and concurrently affects brain connectivity. Nat. Commun. 2017, 8, 1214. [CrossRef]

149. Edwards, F.A. A Unifying Hypothesis for Alzheimer's Disease: From Plaques to Neurodegeneration. Trends Neurosci. 2019, 42, 310-322. [CrossRef]

150. Mok, S.S.; Losic, D.; Barrow, C.J.; Turner, B.J.; Masters, C.L.; Martin, L.L.; Small, D.H. The beta-amyloid peptide of Alzheimer's disease decreases adhesion of vascular smooth muscle cells to the basement membrane. J. Neurochem. 2006, 96, 53-64. [CrossRef]

151. Castillo, G.M.; Cummings, J.A.; Yang, W.; Judge, M.E.; Sheardown, M.J.; Rimvall, K.; Hansen, J.B.; Snow, A.D. Sulfate content and specific glycosaminoglycan backbone of perlecan are critical for perlecan's enhancement of islet amyloid polypeptide (amylin) fibril formation. Diabetes 1998, 47, 612-620. [CrossRef] [PubMed]

152. Herold, C.; Hooli, B.V.; Mullin, K.; Liu, T.; Roehr, J.T.; Mattheisen, M.; Parrado, A.R.; Bertram, L.; Lange, C.; Tanzi, R.E. Family-based association analyses of imputed genotypes reveal genome-wide significant association of Alzheimer's disease with OSBPL6, PTPRG, and PDCL3. Mol. Psychiatry 2016, 21, 1608-1612. [CrossRef] [PubMed]

153. Snow, A.D.; Mar, H.; Nochlin, D.; Kimata, K.; Kato, M.; Suzuki, S.; Hassell, J.; Wight, T.N. The presence of heparan sulfate proteoglycans in the neuritic plaques and congophilic angiopathy in Alzheimer's disease. Am. J. Pathol. 1988, 133, 456-463. [PubMed]

154. Lepelletier, F.X.; Mann, D.M.; Robinson, A.C.; Pinteaux, E.; Boutin, H. Early changes in extracellular matrix in Alzheimer's disease. Neuropathol. Appl. Neurobiol. 2017, 43, 167-182. [CrossRef] [PubMed]

155. Verbeek, M.M.; Otte-Holler, I.; van den Born, J.; van den Heuvel, L.P.; David, G.; Wesseling, P.; de Waal, R.M. Agrin is a major heparan sulfate proteoglycan accumulating in Alzheimer's disease brain. Am. J. Pathol. 1999, 155, 2115-2125. [CrossRef]

156. van Horssen, J.; Otte-Holler, I.; David, G.; Maat-Schieman, M.L.; van den Heuvel, L.P.; Wesseling, P.; de Waal, R.M.; Verbeek, M.M. Heparan sulfate proteoglycan expression in cerebrovascular amyloid beta deposits in Alzheimer's disease and hereditary cerebral hemorrhage with amyloidosis (Dutch) brains. Acta Neuropathol. 2001, 102, 604-614. [CrossRef]

157. Li, L.; Liu, F.; Welser-Alves, J.V.; McCullough, L.D.; Milner, R. Upregulation of fibronectin and the alpha5beta1 and alphavbeta3 integrins on blood vessels within the cerebral ischemic penumbra. Exp. Neurol. 2012, 233, 283-291. [CrossRef]

158. Hawkes, C.A.; Sullivan, P.M.; Hands, S.; Weller, R.O.; Nicoll, J.A.; Carare, R.O. Disruption of arterial perivascular drainage of amyloid-beta from the brains of mice expressing the human APOE epsilon4 allele. PLOS ONE 2012, 7, e41636. [CrossRef]

159. Jullienne, A.; Roberts, J.M.; Pop, V.; Paul Murphy, M.; Head, E.; Bix, G.J.; Badaut, J. Juvenile traumatic brain injury induces long-term perivascular matrix changes alongside amyloid-beta accumulation. J. Cereb. Blood Flow Metab. 2014, 34, 1637-1645. [CrossRef]

160. Manich, G.; Mercader, C.; del Valle, J.; Duran-Vilaregut, J.; Camins, A.; Pallas, M.; Vilaplana, J.; Pelegri, C. Characterization of amyloid-beta granules in the hippocampus of SAMP8 mice. J. Alzheimers Dis. 2011, 25, 535-546. [CrossRef] 
161. Lam, V.; Takechi, R.; Pallebage-Gamarallage, M.M.; Galloway, S.; Mamo, J.C. Colocalisation of plasma derived apo B lipoproteins with cerebral proteoglycans in a transgenic-amyloid model of Alzheimer's disease. Neurosci. Lett. 2011, 492, 160-164. [CrossRef] [PubMed]

162. Timmer, N.M.; Herbert, M.K.; Kleinovink, J.W.; Kiliaan, A.J.; De Waal, R.M.; Verbeek, M.M. Limited expression of heparan sulphate proteoglycans associated with Abeta deposits in the APPswe/PS1dE9 mouse model for Alzheimer's disease. Neuropathol. Appl. Neurobiol. 2010, 36, 478-486. [CrossRef] [PubMed]

163. Iivonen, S.; Helisalmi, S.; Mannermaa, A.; Alafuzoff, I.; Lehtovirta, M.; Soininen, H.; Hiltunen, M. Heparan sulfate proteoglycan 2 polymorphism in Alzheimer's disease and correlation with neuropathology. Neurosci. Lett. 2003, 352, 146-150. [CrossRef] [PubMed]

164. Rosenmann, H.; Meiner, Z.; Kahana, E.; Aladjem, Z.; Friedman, G.; Ben-Yehuda, A.; Grenader, T.; Wertman, E.; Abramsky, O. An association study of a polymorphism in the heparan sulfate proteoglycan gene (perlecan, HSPG2) and Alzheimer's disease. Am. J. Med. Genet. B Neuropsychiatr. Genet. 2004, 128B, 123-125. [CrossRef]

165. Lashley, T.; Holton, J.L.; Verbeek, M.M.; Rostagno, A.; Bojsen-Moller, M.; David, G.; van Horssen, J.; Braendgaard, H.; Plant, G.; Frangione, B.; et al. Molecular chaperons, amyloid and preamyloid lesions in the BRI2 gene-related dementias: A morphological study. Neuropathol. Appl. Neurobiol. 2006, 32, 492-504. [CrossRef]

166. Wien, T.N.; Sorby, R.; Omtvedt, L.A.; Landsverk, T.; Husby, G. Kinetics of glycosaminoglycan deposition in splenic AA amyloidosis induced in mink. Scand. J. Immunol. 2004, 60, 600-608. [CrossRef]

167. Guo, Z.; Mori, M.; Fu, X.; Yao, J.; Xing, Y.; Korenaga, T.; Li, G.; Matsushita, T.; Hosokawa, M.; Higuchi, K. Amyloidosis modifier genes in the less amyloidogenic a/j mouse strain. Lab. Invest. 2003, 83, 1605-1613. [CrossRef]

168. van Horssen, J.; Kleinnijenhuis, J.; Maass, C.N.; Rensink, A.A.; Otte-Holler, I.; David, G.; van den Heuvel, L.P.; Wesseling, P.; de Waal, R.M.; Verbeek, M.M. Accumulation of heparan sulfate proteoglycans in cerebellar senile plaques. Neurobiol. Aging 2002, 23, 537-545. [CrossRef]

169. Gu, Y.H.; Kanazawa, M.; Hung, S.Y.; Wang, X.; Fukuda, S.; Koziol, J.A.; Del Zoppo, G.J. Cathepsin L acutely alters microvessel integrity within the neurovascular unit during focal cerebral ischemia. J. Cereb. Blood Flow Metab. 2015, 35, 1888-1900. [CrossRef]

170. Kahle, M.P.; Lee, B.; Pourmohamad, T.; Cunningham, A.; Su, H.; Kim, H.; Chen, Y.; McCulloch, C.E.; Barbaro, N.M.; Lawton, M.T.; et al. Perlecan domain V is upregulated in human brain arteriovenous malformation and could mediate the vascular endothelial growth factor effect in lesional tissue. Neuroreport 2012, 23, 627-630. [CrossRef]

171. Guyton, J.R.; Rosenberg, R.D.; Clowes, A.W.; Karnovsky, M.J. Inhibition of rat arterial smooth muscle cell proliferation by heparin. In vivo studies with anticoagulant and nonanticoagulant heparin. Circ. Res. 1980, 46, 625-634. [CrossRef] [PubMed]

172. McGuire, P.G.; Brocks, D.G.; Killen, P.D.; Orkin, R.W. Increased deposition of basement membrane macromolecules in specific vessels of the spontaneously hypertensive rat. Am. J. Pathol. 1989, 135, 291-299. [PubMed]

173. Hijmans, R.S.; Shrestha, P.; Sarpong, K.A.; Yazdani, S.; El Masri, R.; de Jong, W.H.A.; Navis, G.; Vives, R.R.; van den Born, J. High sodium diet converts renal proteoglycans into pro-inflammatory mediators in rats. PLoS ONE 2017, 12, e0178940. [CrossRef] [PubMed]

174. Lipke, D.W.; McCarthy, K.J.; Elton, T.S.; Arcot, S.S.; Oparil, S.; Couchman, J.R. Coarctation induces alterations in basement membranes in the cardiovascular system. Hypertension 1993, 22, 743-753. [CrossRef] [PubMed]

175. Weissgerber, T.L.; Garcia-Valencia, O.; Milic, N.M.; Codsi, E.; Cubro, H.; Nath, M.C.; White, W.M.; Nath, K.A.; Garovic, V.D. Early Onset Preeclampsia Is Associated With Glycocalyx Degradation and Reduced Microvascular Perfusion. J. Am. Heart Assoc. 2019, 8, e010647. [CrossRef] [PubMed]

176. Szenasi, N.L.; Toth, E.; Balogh, A.; Juhasz, K.; Karaszi, K.; Ozohanics, O.; Gelencser, Z.; Kiraly, P.; Hargitai, B.; Drahos, L.; et al. Proteomic identification of membrane-associated placental protein 4 (MP4) as perlecan and characterization of its placental expression in normal and pathologic pregnancies. PeerJ 2019, 7, e6982. [CrossRef]

177. Guo, H.X.; Zhu, Y.B.; Wu, C.P.; Zhong, M.; Hu, S.W. Potential urine biomarkers for gestational hypertension and preeclampsia. Mol. Med. Rep. 2019, 19, 2463-2470. [CrossRef] 
178. Bix, G.J.; Gowing, E.K.; Clarkson, A.N. Perlecan domain V is neuroprotective and affords functional improvement in a photothrombotic stroke model in young and aged mice. Transl. Stroke Res. 2013, 4, 515-523. [CrossRef]

179. Clarke, D.N.; Al Ahmad, A.; Lee, B.; Parham, C.; Auckland, L.; Fertala, A.; Kahle, M.; Shaw, C.S.; Roberts, J.; Bix, G.J. Perlecan Domain V induces VEGf secretion in brain endothelial cells through integrin alpha5beta1 and ERK-dependent signaling pathways. PLOS ONE 2012, 7, e45257. [CrossRef]

180. Kahle, M.P.; Bix, G.J. Neuronal restoration following ischemic stroke: Influences, barriers, and therapeutic potential. Neurorehabil. Neural. Repair 2013, 27, 469-478. [CrossRef]

(C) 2020 by the authors. Licensee MDPI, Basel, Switzerland. This article is an open access article distributed under the terms and conditions of the Creative Commons Attribution (CC BY) license (http://creativecommons.org/licenses/by/4.0/). 